\title{
Algorithm for constructing an organizational and technological model for dismantling NPP buildings
}

\author{
Igor Engovatov and Zhanna Kovalenko
}

Moscow State University of Civil Engineering, Yaroslavskoe shosse, 26, Moscow, 129337, Russia

\begin{abstract}
In coming decade the practical implementation of work on the decommissioning of nuclear power plants will begin. Failure to take into account the decommissioning stage for NPPs of the first generations, the presence of a radiation component in the building structures of NPP buildings and structures, the need to destroy protective barriers are the main problems in the issue of dismantling works. The destruction of barriers and the specifics of dismantling technological processes can lead to the release of radioactivity into the environment, which will lead to an increase in the radiation load on personnel and the population.

Radioactive contamination of structures leads to the formation of a large volume of radioactive waste, the amount of which can be significantly reduced due to the competent separation of waste into classes, taking into account the holding time.

In this study the design of the reactor building for unit 1 of the Novovoronezh NPP was considered. Based on the analysis of the data of the comprehensive engineering and radiation surveys (CERS), which was completed in 2004, a classification of buildings into three groups was proposed.

Based on the results of CERS, the dependences of the total activity of the main radionuclides and the cost of maintaining the block under observation from time are presented.

As a result of the performed studies, an algorithm for constructing an organizational and technological model for dismantling buildings and structures of NPP that are being decommissioned is proposed.
\end{abstract}

\section{Introduction}

Currently the number of NPP power units stopped and finalizing their design service life is growing and the search for possible options for increasing the economic, efficient and safe component of the NPP decommissioning process is an urgent problem around the world [1$6]$.

In Russia, at the moment, 7 power units have been stopped and are being prepared for decommissioning. In the period up to 2030 their number will increase to 19 [7].

For the decommissioning of NPP the option of immediate liquidation is increasingly used. Based on the results of the feasibility study for Units 1 and 2 of the Novovoronezh NPP in 2017, a decision was made to switch from the "deferred dismantling" option with completion of work in 2074 to the "immediate dismantlement" strategy with completion of work in 2035 . Which will save up to $20 \%$ of financial costs [7]. 
The implementation of a set of decommissioning works at these units will make it possible to form organizational and technological solutions that will form the basis for the creation of a domestic base for the decommissioning of NPP [8].

The main problems today when performing dismantling works are:

- lack of design solutions for decommissioning for first-generation NPPs;

- partial or complete destruction of protective barriers during dismantling, which prevent the release of radioactivity into the environment;

- the presence of radionuclides in building structures accumulated during the operation period, which, as a result of dismantling, lead to the formation of a large amount of radioactive waste and pose a potential danger to personnel, the public and the environment [9-14].

\section{Main part}

To solve the indicated problems, taking into account the safe implementation of dismantling works and minimizing damage for all participants in the decommissioning process, it is necessary to build an algorithm for the organizational and technological sequence of dismantling works.

After completing all the necessary steps, an organizational and technological model of dismantling the structures of buildings and structures of decommissioned nuclear power plants will be obtained. This model will take into account the reduction of radiation waste, reuse of the bulk of the dismantled material, a decrease in the financial component and, most importantly, minimizing the excess of dose loads on personnel, population and the environment $[1,9]$.

In this study the basic principles of building a model were highlighted using the example of the reactor compartment of unit 1 of the decommissioned Novoronezh NPP with a reactor PWR-210.

The reactor building 1 of the NVNPP unit is a single-span frame building made of prefabricated elements, which are supported by a rigid box-shaped structure of monolithic reinforced concrete walls and ceilings. The dimensions of the building are $39 \mathrm{~m}$ by $72 \mathrm{~m}$ in plan, $38 \mathrm{~m}$ high [8].

To assess the radiation state of buildings and structures of Unit 1 of NVNPP in 2004 a comprehensive engineering and radiation survey (CERS) was carried out. Based on the results of this study, all premises of the NPP can be divided into three groups according to the dose rate of gamma radiation. The first group includes premises where the dose rate is above $100 \mu \mathrm{R} / \mathrm{sec}$, the second - more than $10 \mu \mathrm{R} / \mathrm{sec}$, and the third group includes premises with a dose rate of less than $10 \mu \mathrm{R} / \mathrm{sec}$.

In table 1, as an example, data are presented for some rooms of the reactor building after the CERS 1 of the NVNPP unit $[8,16]$.

Table 1. An example of a cartogram of the dose rate of g-radiation in the premises of the reactor building of the NVNPP unit 1 .

\begin{tabular}{|c|l|l|c|c|c|}
\hline \multirow{2}{*}{$№$} & \multirow{2}{*}{$\begin{array}{c}\text { Room } \\
\text { number }\end{array}$} & The name of a room & $\begin{array}{c}\text { Rom } \\
\text { category }\end{array}$ & $\begin{array}{c}\text { g-radiation } \\
\text { medium, } \\
\mu \mathrm{R} / \mathrm{sec}\end{array}$ & $\begin{array}{c}\text { g-radiation } \\
\mathrm{max}, \\
\mu \mathrm{R} / \mathrm{sec}\end{array}$ \\
\hline 1 & 2 & 3 & 4 & 5 & 6 \\
\hline 1 & $\mathrm{~A} 222 / 1$ & Box MCP-1 & 1 & 6,0 & 250,0 \\
\hline 2 & $\mathrm{~A} 222 / 2$ & Box MCP - 2 & 1 & 5,0 & 100,0 \\
\hline 3 & $\mathrm{~A} 222 / 3$ & Box MCP -3 & 1 & 3,5 & 100,0 \\
\hline 4 & $\mathrm{~A} 222 / 4$ & Box MCP -4 & 1 & 10,0 & 120,0 \\
\hline
\end{tabular}




\begin{tabular}{|c|l|l|c|c|c|}
\hline 5 & A222/5 & Box MCP -5 & 1 & 9,0 & 150,0 \\
\hline 6 & A222/6 & Box MCP -6 & 1 & 11,0 & 250,0 \\
\hline 7 & A223 & Transport (rail) corridor & 3 & 0,3 & 0,6 \\
\hline 8 & A026 & $\begin{array}{l}\text { Room for the tank No.1 } \\
\text { of the "dirty" condensate } \\
\text { from the pools }\end{array}$ & 1 & 10,0 & 220,0 \\
\hline 9 & A225/4 & $\begin{array}{l}\text { Reactor loop connection } \\
\text { chambers }\end{array}$ & 1 & 15,0 & 100,0 \\
\hline 10 & A225/5 & $\begin{array}{l}\text { Reactor loop connection } \\
\text { chambers }\end{array}$ & 1 & 15,0 & 100,0 \\
\hline 11 & A225/6 & $\begin{array}{l}\text { Reactor loop connection } \\
\text { chambers }\end{array}$ & 1 & 12,0 & 120,0 \\
\hline 12 & A301 & $\begin{array}{l}\text { Room of storage tanks } \\
\text { for gas from the volume } \\
\text { compensator }\end{array}$ & 2 & 1,5 & 10,0 \\
\hline 13 & A303 & $\begin{array}{l}\text { Room for the volume } \\
\text { compensator }\end{array}$ & 2 & 2,0 & 30,0 \\
\hline
\end{tabular}

Analyzing the information in Table 1 and taking into account the accepted classification, the selected premises were divided into three groups (Table 2).

Table 2. Classification of the considered premises of the reactor building 1 of the NVNPP unit.

\begin{tabular}{|c|c|c|}
\hline Room classification group & Dose rate of g-radiation & Premises of block No. 1 \\
\hline I group & above $100 \mu \mathrm{R} / \mathrm{sec}$ & A222/1-6, A026, A225/4-6 \\
\hline II group & above $10 \mu \mathrm{R} / \mathrm{sec}$ & A301, A303 \\
\hline Ш group & less than $10 \mu \mathrm{R} / \mathrm{sec}$ & A223 \\
\hline
\end{tabular}

Spectrometric measurements showed that the main radionuclides that determine the radioactive contamination of building materials and structures and form radiation fields are ${ }^{137} \mathrm{Cs},{ }^{60} \mathrm{Co},{ }^{134} \mathrm{Cs},{ }^{54} \mathrm{Mn}$, and ${ }^{90} \mathrm{Sr}+{ }^{90} \mathrm{Y}$ (determining surface contamination with $\beta$-particles. The activity of surface contamination of building and protective concrete is mainly determined by the radionuclide ${ }^{137} \mathrm{Cs}$. Moreover, more than $80 \%$ of surface activity is concentrated in the first layers $5-10 \mathrm{~mm}$ thick of building and protective structures $[8,15$, $16]$.

The averaged data for 2004 make it possible to determine the ratio and contribution to the total specific activity for each nuclide ${ }^{137} \mathrm{Cs}:{ }^{60} \mathrm{Co}:{ }^{134} \mathrm{Cs}:{ }^{54} \mathrm{Mn}$ as $80 \%: 17 \%$ : $1 \%$ : $1 \%$, respectively. Table 3 shows the calculated results of the dynamics of changes in specific activity for each radionuclide, taking into account radioactive decay. 2004 was taken as a starting point and the forecast was made for 2021 (17 years) and 2034 (30 years).

Table 3. Dynamics of changes in specific activity taking into account radioactive decay.

\begin{tabular}{|c|c|}
\hline $\begin{array}{c}\text { Activity ratio } \\
{ }^{137} \mathrm{Cs}:{ }^{60} \mathrm{Co}:{ }^{134} \mathrm{Cs}:{ }^{54} \mathrm{Mn}\end{array}$ & \\
\hline 2004 & ${ }^{137} \mathrm{Cs}-80 \%:{ }^{60} \mathrm{Co}-18 \%:{ }^{60} \mathrm{Cs}-1 \%:{ }^{54} \mathrm{Mn}-1 \%$ \\
\hline $2021-17$ years & $\begin{array}{c}{ }^{137} \mathrm{Cs}-54,45 \%:{ }^{60} \mathrm{Co}-1,98 \%:\left({ }^{134} \mathrm{Cs}-: \cdot{ }^{54} \mathrm{Mn}-\mathrm{can} \text { be }\right. \\
\text { neglected })\end{array}$ \\
\hline 2034-30 years & $\begin{array}{c}{ }^{137} \mathrm{Cs}-40 \%:{ }^{60} \mathrm{Co}-0,36 \%:\left({ }^{60} \mathrm{Cs}-:{ }^{54} \mathrm{Mn}-\mathrm{can} \text { be }\right. \\
\text { neglected })\end{array}$ \\
\hline
\end{tabular}


The data obtained allow us to conclude that already 17 years after the CERS in 2004 the contribution to the total activity ${ }^{137} \mathrm{Cs}$ is slightly more than $50 \%$, contribution ${ }^{60} \mathrm{Co}$ near $2 \%$, the contribution of ${ }^{134} \mathrm{Cs}$ and ${ }^{54} \mathrm{Mn}$ can be neglected. Similar data in terms of 2034 show that the contribution ${ }^{137} \mathrm{Cs}$ is $40 \%$, and ${ }^{60} \mathrm{Co}$ is less than $1 \%$.

In 2018 at a meeting of the Scientific and Technical Council of Rosenergoatom JSC the amount of costs for decommissioning units 1, 2 of NVNPP under the option of "immediate liquidation" with completion of work in 2035 was presented. Costs amount to RUB 30.2 billion assuming uniform spending over the period from 2004 to 2035. - or about 1 billion per year.

Figure 1 shows the graphs of changes in the radiation situation for this time interval (curve 1) and the increase in costs over time until the completion of the work (line 2). The results obtained make it possible to determine the optimal (in terms of costs and radiation factor) start date for practical decommissioning work. In this case, this period is 2021.

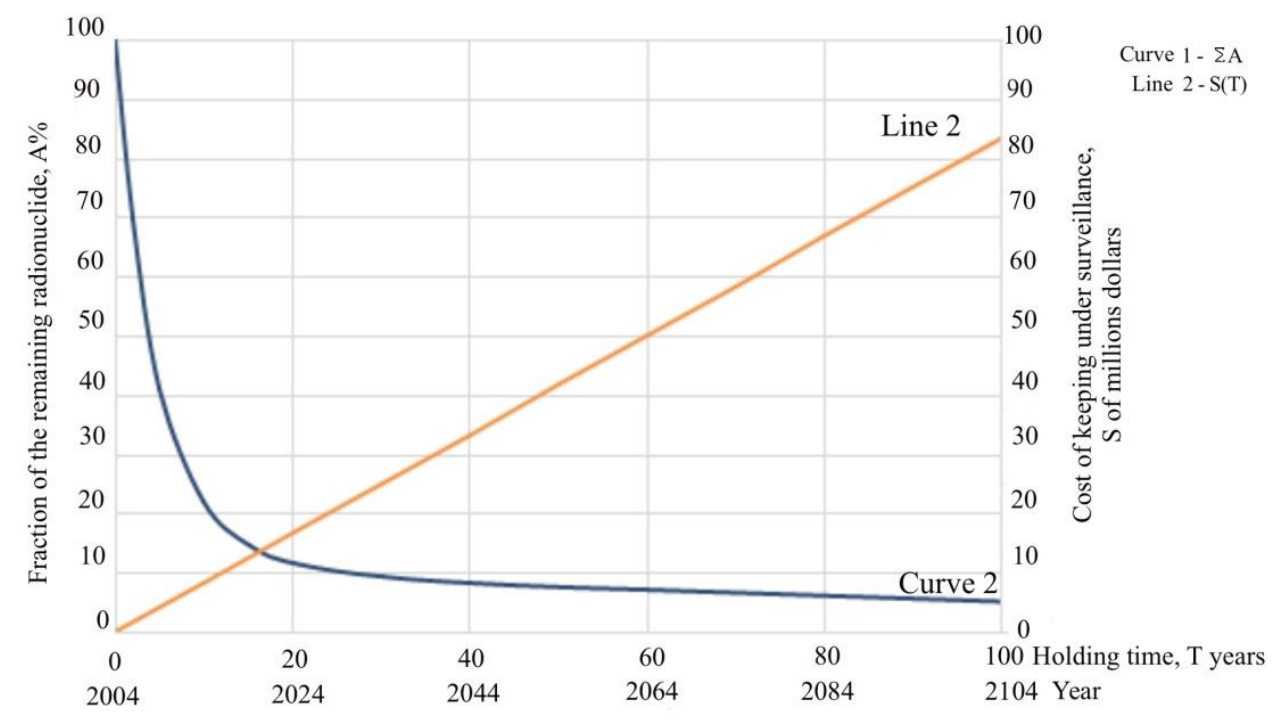

Fig. 1. Graphs of changes in the specific activity of rooms contaminated with radionuclides in the reactor building 1 of the NVNPP unit and changes in the amount of costs for decommissioning.

As a result of dismantling works of the reactor compartment of unit 1 of NVNPP, about $15,000 \mathrm{~m}^{3}$ of concrete waste is generated. Using the data of surface radiation contamination and the volume of building structures, it is possible to approximately determine the amount of radioactive waste of various classes for the reactor building 1 of the NVNPP unit, generated as a result of dismantling work.

An important aspect in conducting CERS is to determine the minimum and sufficient list of research performance. For example, when performing, in addition to surface measurements, also deep measurements, data analysis will show that the thickness of the contaminated layer of concrete building and protective structures, in which the material should be considered radioactive waste, does not exceed 15-25 $\mathrm{mm}$ [9].

This information will entail the need to change the technological sequence of dismantling works, taking into account the work on separation and decontamination of waste, which will reduce the amount of radioactive waste, and return part of the material from dismantled structures to reuse. With proper separation high and intermediate level waste makes up only $20 \%$ of the total mass of dismantled structures. These measures will 
significantly affect the total cost of work, taking into account the high cost of disposal of $1 \mathrm{~m}^{3}$ of radioactive waste (Table 4) [17-20].

Table 4. Tariffs for the disposal of radioactive waste in $\mathrm{RUB} / \mathrm{m}^{3}$.

\begin{tabular}{|c|c|c|c|c|c|}
\hline $\begin{array}{c}\text { Radioactive } \\
\text { class } \\
\text { waste }\end{array}$ & 2018 & 2019 & 2020 & 2021 & 2022 \\
\hline 1 & 1368421,94 & 1423535,61 & 1473359,35 & 1521980,21 & 1569161,6 \\
\hline 2 & 635964,56 & 661578,26 & 684733,5 & 707329,7 & 729256,92 \\
\hline 3 & 146569,87 & 152473,02 & 157809,58 & 163017,3 & 168070,83 \\
\hline
\end{tabular}

In order to prevent the spread of ionizing radiation and radioactive substances into the atmosphere dismantling is carried out from top to bottom according to the principle from the least radiation hazardous objects to the most dangerous. It is advisable to dismantle the roof and external walls of buildings last. This solution makes it possible to carry out the dismantling of internal structures without fear of harmful emissions into the environment.

Thus, the algorithm for constructing an organizational and technological model for dismantling structures of buildings and structures during decommissioning of nuclear power plants is as follows:

1. Information about the decommissioning facility is collected and analyzed.

2. A comprehensive engineering and radiation survey of the NPP premises is carried out in order to divide the premises into sanitary zones according to the degree of contamination.

3 . The volumes of the dismantled structures must be calculated.

4. The dismantled materials are sorted into radioactive waste and waste, which can be returned to production in order to reduce solid radioactive waste.

5. The optimal start time for decommissioning works is determined based on the graph of the dependences of the remaining radionuclide and the cost of keeping under observation from time.

6. Dismantling is carried out with the choice of the priority of the premises: from the least polluted premises to the more polluted.

As a result by combining the indicated steps into a technological sequence, we will obtain an organizational and technological model for dismantling the structures of buildings and structures decommissioned from nuclear power plants, taking into account the reduction of radiation waste, reuse of the bulk of the dismantled material, a decrease in the financial component and, most importantly, minimizing the excess of dose loads on personnel., population and environment (Fig. 2). 


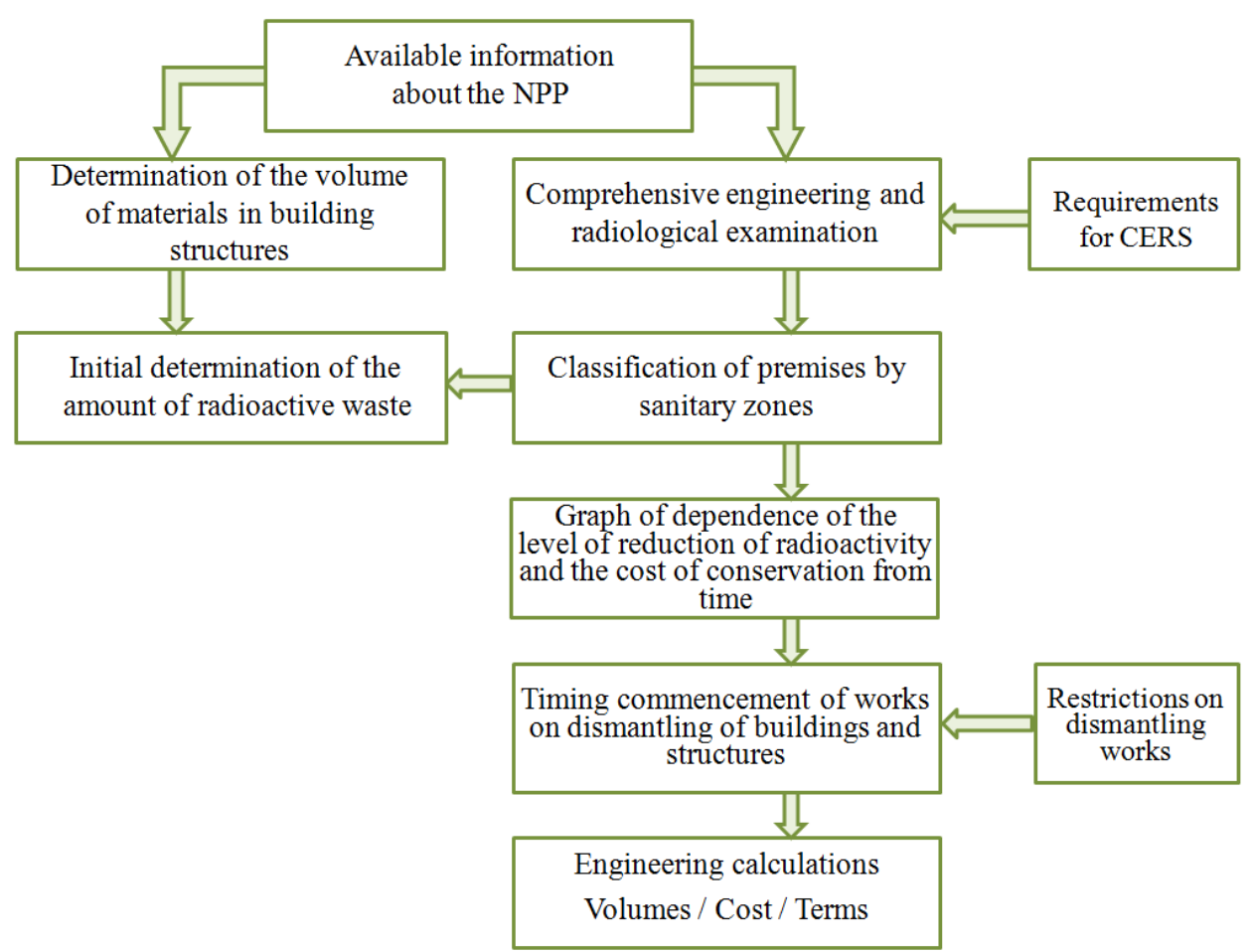

Fig. 2. Organizational and technological model of dismantling the structures of buildings and structures of nuclear power plants.

\section{References}

1. B. K. Bylkin, I. A. Engovatov. Decommissioning of Reactor Plants. Moscow, NIU MGSU, 228 p. (2014).

2. Decommissioning of NPP and Research Reactors. №WS-G-2.1. IAEA, Vienna. (1999).

3. Decommissioning of Facilit. Using Radioac. Mat., №.WS-R-5, IAEA, Vienna. (2006).

4. Decommissioning Strat. for Facilit. Using Radioac. Mat.. №50. IAEA, Vienna. (2007).

5. Selecting Strategies for the Decommissioning of Nuclear Facilities. NEA №6038. OECD. (2006).

6. The concept of preparation and decommissioning of nuclear power plant units of Rosenergoatom Concern JSC (2017).

7. Decision of the meeting of the NTS of JSC "Concern Rosenergoatom" dated 26.07.2016 on the issue "Problems of decommissioning of nuclear power units of the 1st and 2nd generations". JSC "Concern Rosenergoatom" (2016).

8. B. K. Bylkin, U.A. Zverkov, I. A. Engovatov. Fundamentals of decommissioning of nuclear power plant units. (2019).

9. I. A. Engovatov, Zh. A. Kovalenko. Specifics of dismantling decommissioned buildings and structures at nuclear power plants. №12(1). P. 33-37. (2020).

10. C. Paperello. Restoration Principles and Criteria. №1092. Vienna, p. 239 - 255. (2000).

11. The best foreign practices of decommissioning of nuclear installations and rehabilitation of contaminated territories: Volume 1. 366 p. (2017).

12. Best foreign practices of decommissioning of nuclear installations and rehabilitation of contaminated territories: Volume 2. 187 p. (2017). 
13. M. Laraia Nuclear Decommissioning. Planning, Execution and International Experience. Woodhead Publishing Limited. 805 p. (2012).

14. Problems of the nuclear legacy and ways to solve them. Decommissioning. Under the general editorship of L. A. Bolshov, N. P. Laverov, and I. I. Linge.- Moscow. 316 p. vol. 3. (2015).

15. I.A. Engovatov, V.P. Mashkovich, Y.V. Orlov, B.G. Pologikh, N.S. Khlopkin, S.G. Tsypin. Radiation Safety Assurance: Decommissioning Nuclear Reactors at Civil and Military Installations. Arlington, 201 p. (2005).

16. Report on the results of a comprehensive engineering and radiation survey of Novovoronezh NPP units no. 1 and 2. Moscow. (2004).

17. Federal Law No. 190-FZ of 11.07.2011" On the Management of Radioactive Waste and on Amendments to Certain Legislative Acts of the Russian Federation". (2011).

18. Criteria for classifying solid, liquid and gaseous waste as radioactive waste. Resolution of the Government of the Russian Federation of October 19, 2012 N 1069 (2015).

19. E. A. Ivanov, A. S. Korotkov, I. V. Pyrkov. Radionuclide vector. Rosenergoatom. №1. P. 42-45. (2015).

20. Order of the Federal Antimonopoly Service of December 28, 2017 № 1812/17" On the establishment of tariffs for the disposal of radioactive waste of classes 1, 2, 3, 4, 6 for the period from 2018 to 2022 and tariffs for the disposal of radioactive waste of class 5 for $2018 "$ 